\title{
A Critique of Contemporary Classification of English Words into Lexical (Grammatical) Categories
}

\author{
${ }^{1}$ Ishaya Yusuf Tsojon (Mr.), ${ }^{2}$ Mrs. Blessing Ijem Ginikanwa, ${ }^{3} \mathrm{Mr}$. Yakubu \\ Samaila \\ ${ }^{1,2,3}$ Department of English and Literary Studies, Federal University Wukari P.M.B. 1020, Wukari, Taraba State
}

\begin{abstract}
There may be no any meaningful spoken or written discourse in any human language without words because words are used to express thoughts, ideas and feelings. For one to use any word correctly, one requires among other things, the knowledge of its lexical or grammatical category. Several contemporary scholars of English grammar have identified certain criteria for classifying English words into grammatical categories. But some of these criteria are somewhat controversial. Hence this paper is a critique of the criteria identified by these contemporary English grammarians. However, it considers briefly traditional grammar approach to the classification of English words. The paper discusses both open set and closed set words which are randomly selected and analyzed. The study discovered that virtually all the grammatical categories have homophonous usage with one another. That is, their features tend to overlap. It also discovered that no single criterion is satisfactory enough for use in classifying English words into grammatical categories. The paper therefore posits that in classifying English words into lexical categories, we need to consider both the morphology and distribution (syntax) of words because none of them is self-sufficient in this regard.
\end{abstract}

\section{Introduction}

Words are an integral component of human communication or language. Finegan (2004:64) commenting on the place of words in language maintains that, "words are the centre-piece of language, and when you think about language you typically think of words". He adds that the most tangible elements of a language are its words.

English words belong to a restricted set of grammatical categories: a class of expressions which share a common set of grammatical properties - Radford (1997:). The categories include nouns, verbs, adjectives, adverbs, pronouns, prepositions, auxiliary verbs, infinitival to, determiners, complementizers and conjunctions.

Traditional linguists - Quirk and Greenbaum (1973) among others, classify words on the basis of semantics (meaning). For example, they regard noun as a name of a person, animal, place or thing, and consider any word with any of these attributes a noun. But $20^{\text {th }}$ century linguists consider this definition as unsatisfactory which is also the position of this paper. Carnie (2007:38) argues that traditional notion is "very oversimplistic way to characterize various parts of speech. It is also not terribly scientific or accurate". He further argues that "if parts of speech are based on the meaning of the word, how can we assign a part of speech to a word which the meaning isn't clear?

This paper supports Carnie's argument. For instance, the word "planted", going by the traditional notion of grammatical categories is a verb if it is used in isolation. But in the structure: the crops planted are germinating as expected.

"Planted becomes an adjective post-modifying the noun "crops". Hence this paper like the modern linguists posits that both form (morphology) and function (syntax) of words must be considered when classifying words into grammatical categories. This view is supported by Carnie (38) as follows: "the definitions for the various parts of speech are not semantically defined. Instead they depend on where the words appears in the sentence and what kinds of affixes they take..." He adds that a word can change its part of speech depending upon where it appears in a sentence.

In fact, a word cannot be classified satisfactorily in isolation. Huddleston (1988) buttresses this assertion thus, "A major problem in presenting the grammar of language is that the various categories are closely inter-related: we cannot give a definition of one category at the language particular level, without making reference to other categories". Radford (1997) supports this with his "Structure Dependence Principle" "All grammatical operations in national language are category based (so that any word-based operation will apply to whole categories of words rather than to specific individual words".

Writing on lexical categories, Eka (1994) holds that "in attempting to put the words, groups of words or utterances of a particular language into categories, it is important to emphasize the interdependence of the items 
and their context of operation. This is necessary because a given word... may belong to various grammatical categories, depending on the use to which it is put".

Modern granmmarians such as Radford maintain that words are classified based on both morphological and syntactic criteria. Unlike syntactic criterion, morphological criterion concerns the classification of words on the basis of their inflectional and derivational properties. That we can determine the categorical status of a word from its morphological properties.

Inflection refers to different forms which a particular word takes. So to classify English words using inflectional properties, we try to find out which words are closely related in certain forms. For instance, which ones take plural form by the addition of $-\mathrm{s}$ suffix.

Derivational properties relate to the processes by which a word can be used to form a different kind of word by the addition of another morpheme. For instance, by adding the suffix -ly to the word "brother" (noun), an adjective, "brotherly" is formed. By adding the suffix, -ness to meek" (adjective), a noun meekness is formed.

Suffice it to say derivational morphemes change the category of a word but inflectional morphemes do not, they only attach it to certain categories. For clarity, we shall discuss each syntactic category.

\section{Nouns:}

Morphologically, nouns inflect for number and thus have (potentially) distinct singular and plural forms. Words like "ball", "plate" and "spoon", which are all nouns, show parallel patterns of related forms. All of them take $-\mathrm{s}$ suffix to denote plural. But it is quite true that not all nouns become plural by the addition of $-\mathrm{s}$ suffix or suffixes like ies, -en and others. Instead they change vowel (phonetically), as in "goose"- "geese", "man", "men" and foreign plurals like "stratum", "strata", "datum" - "data", "bacterium"- "bacteria". Some nouns do not even have singular forms. Examples include trousers, scissors, equipment. Huddleston supports this by saying "there are many nouns without a contrast of number: equipment, muck, wetness and the like have no plural counterparts, while a few such as alms, dregs, remains, have no singular counterparts".

All these points are to the complications involved in using this criteria to classify nouns. We observe too that nouns can equally be formed from other words particularly adjectives using derivational properties as in "kind" (adjective) - "kindness" (noun), "promote" (verb) - "promotion" (noun), "locate" (verb) - "location" (noun). In fact, ion is a highly productive nominal suffix. But we need to know too that some ion suffix words are not nouns particularly when they are syntactically used or even in phrases as in "promotion letter", "location study" where both promotion and location are adjectives.

Syntactically too, grammarians have argued that nouns are preceded (in certain structures) by determiners: the, that, these, those etc as in the book, those cars. But is this limited to only nouns? What about generic adjectives functioning as HEAD of a noun phrase (NP) - the mek, the poor, the rich, the down-trodden, etc and even adjectives in the structures below?

\section{- $\quad$ The good student is reading}

The big table is in the room

Carnie (42) argues that a noun can be replaced with another word that is clearly a noun in a sentence as in " $\mathrm{He}$ closed the door. He closed the book.

But we observed too that substitution is not limited to nouns. Other parts of speech such as verbs, adjectives, adverbs, preposition also undergo substitution as in:

- He touched the lady - He called the lady

- The book is on the table - the book is under the table

- The brilliant student passed - the intelligent student passed

- He talks very slowly - He talks very fast

\section{Verbs}

Verbs to some extent can be classified by their inflectional morphology. Apart from their base form which is not inflected, they have four different forms with different suffixes which unlike those of nouns refer to tenses rather than number.

Radford (1997) identifies the tenses as follows: the past / perfective participle denoted by the suffix $+n$, the past tense $+\mathrm{d}$, the third person singular present tesne $+\mathrm{s}$ and the present / imperfective participle $+\mathrm{ing}$ as shown below:

$\begin{array}{llllll}\text { BASE } & +\mathrm{n} & & +\mathrm{d} & +\mathrm{s} & + \text { +ing } \\ \text { show } & \text { shown } & \text { should } & \text { shows } & \text { shoing } & \\ \text { hew } & \text { hewn } & & \text { hewed hews } & & \text { hewing }\end{array}$

The analysis cannot be considered sufficient or adequate because of the irregularities associated with some forms of verbs. Radford even observes that there are verbs with irregular past or perfective forms, and in some 
cases either one or both of these forms may not in fact be distinct from the (uninflected) base form, so that a single form may serve two or three functions (thereby neutralizing the relevant distinctions) as in:

$\begin{array}{cccccc}\text { BASE } & \text { PERFECTIVE } & \text { PAST } & & \text { PRESENT } & \text { IMPERFECTIVE } \\ \text { cut } & \text { cut } & \text { cut } & \text { cuts } & \text { cutting } \\ \text { meet } & \text { met } & & \text { met } & \text { meets } & \text { meeting }\end{array}$

This paper argues that, the word "banned" in the sentence, "He was banned", is a verb. But in, "the banned activist is dead", it becomes an adjective. So, the inflectional morpheme is homophonouns in its usage with other parts of speech. Furthermore, the primary auxiliary verb BE is anomalous; it has eight forms; is, are, am, was, were, be, been, being. This heightens the classification of verbs on the basis of morphology.

\section{Adjectives}

Derivational properties can be used to classify adjectives, as in the use of -er and -est suffixes (comparative and superlative forms); short-shorter-shortest, strong-stronger-strongest. However, there are adjectives which do not take -er and - est suffixes in their comparative and superlative forms. Instead, they take more / most (periphrastic comparison): beautiful - more beautiful - most beautiful, knowledgeable - more knowledgeable - most knowledgeable.

There are a few irregular adjectives in English forming their comparative and superlative by suppletion: good - better - best, bad-worse - worst, little - less - least, much - more - most. Also adjectives take negative prefixes - un, ir, u- etc as in unkind, illogical, irregular.

But we must point out that some of these features are not restricted to adjectives. Carnie (2007:43) says, "note that the following affixes have homophonous usage with other parts of speech: -ing, -er, -ed, un-, ly". For instance, -er, in harder and faster: he worked harder T He runs faster). Here, harder and faster are adverbs inspite of the ier suffix in each of them. Also the periphrastic much / more can be used to qualify adverbs: more carelessly, more carefully, much more quickly (He walked much more quickly than I had thought). Similarly, the prefixes that mark negatives is not limited to adjectives as we can see in the following verbs: undo, unlock, uncover.

Adjectives take different positions going by the syntactic evidence or criteria. Radford (1997) observes that they can be premodified by the intensifiers very, so, too, as in: very good, very bad, very sad, so terrible, so gentle, too hot, too slow. But we observe that not all adjectives take intensifiers. Ungradable adjectives (adjectives which denote an absolute state by virtue of their meaning and which cannot be quantified like gradable adjectives do not take very, rather, somewhat, as in: very present, very absent.

Writing on the syntactic features of adjectives, Carnie (2007:43) says, "adjectives can appear between determiners such as the, a, these etc and nouns (the big peanut)". This is obvious. Adjectives can serve as verb complement (used after the verb be). Radford says, "we can delimit the class of (gradable) adjectives uniquely by saying that only adjectives can be used to complete a four-word sentence of the forms below:

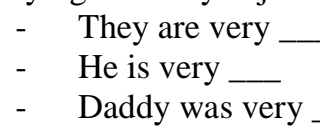

Suffice it to say this distribution overlaps with adverbs as in:

- He works very

- She writes very

So, the intensifiers very also modifies adverbs. It is clear that several (more than one) adjectives can be used attributively. The good old man is here, or predictably: the book, big, brown and old, is mine. But this is also characteristic of adverbs:

- The house I bought more recently is the best in my home town.

- We worked rather very slowly on the farm

- He runs extraordinarily faster than we had thought.

\section{Adverbs}

Morphologically, most adverbs are derived from adjectives by the addition of ly, as in: angry - angrily, careless - carelessly, constant - constantly etc. But there are some adverbs which carry no distinctive marker: here, there, yesterday, today, tomorrow. Besides, some ly words are not adverbs: motherly, likely, friendly, manly, brotherly, fatherly. These inconsistencies complicate the classification of words under this category. Adverbs can take the intensifier very (as earlier mentioned) in the sense of extremely - He worked very hard last semester. 
An adverb can equally modify another adverb - He writes really slowly. As pointed out previously these features overlap with some parts of speech, which also complicate the classification of words as the adverb category.

\section{Preposition}

Another grammatical category is preposition. Radford, like other grammarians, holds that prepositions show relationship between parts of speech, especially in a sentence. Examples include to, for, before, between, across etc. he maintains that, "only preposition can be intensified by right in the sense of completely, or by straight in the sense of directly".

- Come right inside (the room)

- He walked straight to the main

But this is not applicable to prepositions like of, with (non-graddables).

At times prepositions behave like transitive verbs

- $\quad$ I am for you

- Waze came with them

\section{Determiners}

The status of this class remains somewhat controversial. They include a, the, this, that, these, those. They can be quantifiers (referring to quantity) or referential (pointing). They are place in front of nouns, even though they are not adjectives Radford, as in, a book, the man. But this papr posits that certain determiners behave like adjectives syntactically, as in, that chair, those books, my car, this day; This is another complication with classifying such determiners.

\section{Conclusion}

From the foregone discussion we can conclude that neither the morphological nor the syntactic evidence alone is adequate if we must classify English words into lexical or grammatical categories. We must consider both criteria. We must also emphasize form and structure rather than meaning. Besides, a single word might belong to several classes depending on its syntactic usage. So we need to be very careful with words.

\section{Bibliography}

[1]. Carnie, Andrew: Syntax: A Generative Introduction, $2^{\text {nd }}$ edition. Australia: Blackwell Publishers, 2007

[2]. Eka, David. Elements of Grammar and Mechanics of the English Language. Uyo: Samuf (Nigeria) Ltd, 2004.

[3]. Finegan, Edward. Language: Its Structure and Use. USA: Michael Rosenerg, 2004.

[4]. Forest, Ronald. Revision English. UK: Longman Group, 1984

[5]. Huddleston, Rodney. English Grammar: An Outline. Great Britain: Oxford University Press, 1988.

[6]. Muir, James. A Modern Approach to English Grammar: An Introduction to Systemic Grammar. N.p. 1990

[7]. Quirk, Randolph, Sidney Greenbaum, Geoffrey Leech, \& Jan Svartvik. A Grammar of Contemporary English. Great Britain: William Clowes \& Sons Ltd, 1975

[8]. Quirk, Randolph, Sidney Greenbaum, A University Grammar of English. India: Pearson Education (Singapore) Ptc Ltd, 1973

[9]. Radford, Andrew. Syntactic Theory and the Structure of English: A Minimalist Approach: United Kingdom: Cambridge University Press, 1997

[10]. Radford, Andrew: Syntax: A Minimalist Approach: Great Britain: Cambridge University Press, 2007.

[11]. Tom, Mc Arthur (ed): The Oxford Companion to the English Language: abridged edition. Cambridge: Oxford University Press, 1995 